\title{
CUPRAC assay-guided profiling of antioxidant compounds in methanol extract of Lentinus squarrosulus Mont. mycelium
}

\author{
Sumaiyah ABDULLAH ${ }^{* 1,2}$, Noorlidah ABDULLAH ${ }^{2}$, Vikineswary SABARATNAM ${ }^{2}$, Ken Choy YAP ${ }^{3}$ \\ Received November 22, 2017; accepted January 28, 2018. \\ Delo je prispelo 22. novembra 2017, sprejeto 28. januarja 2018.
}

\begin{abstract}
A cupric reducing antioxidant capacity (CUPRAC)-guided purification approach was performed on a methanol extract of Lentinus squarrosulus (LsqMeOH) by using reversed phasehigh performance liquid chromatography. Using reversed phase-high performance liquid chromatography, three fractions were separated arbitrarily named FR1, FR2 and FR3. Results showed that FR2 exhibited the highest antioxidant activity in CUPRAC assay $\left(\mathrm{A}_{450}, 0.86\right)$ but not significantly different from LsqMeOH $\left(\mathrm{A}_{450}, 0.84\right)$. FR1 and FR3 showed much lower absorbance, with values $\left(\mathrm{A}_{450}, 0.21\right)$ and $\left(\mathrm{A}_{450}\right.$, $0.36)$ respectively at $1 \mathrm{mg} \mathrm{ml}^{-1}$. The most active fraction $(\mathrm{F} 3)$ was further subjected to LC-MS/MS to obtain its detailed chemical profile. Uridine, ganoderic acid derivative, and flavonoids were the first time being found in L. squarrosulus antioxidative fractions. The present results indicate that the fraction extracts of $L$. squarrosulus possess antioxidant properties and can be used as free radical inhibitors. Therefore, this research suggested the potentials of $L$. squarrosulus as a source of antioxidant extract to be used in food industries (functional food).
\end{abstract}

Key words: medicinal mushroom; active compounds; Lentinus squarrosulus
IZVLEČEK

\section{CUPRAC TEST ZA LOČITEV ANTIOKSIDACIJSKIH SPOJIN V METANOLNEM IZVLČEKU MICELIJA GLIVE Lentinus squarrosulus Mont.}

Izveden je bil CUPRAC ločitveni postopek metanolnega izvlečka micelija glive Lentinus squarrosulus (LsqMeOH) z uporabo vzratne visoko zmogljive tekočinske kromatografije, kar je dalo tri frakcije, poimenovane FR1, FR2 in FR3. Rezultati so pokazali, da je največjo antioksidacijsko aktivnost v CUPRAC preiskusu pokazala frakcija FR2 (A $\left.\mathrm{A}_{450}, 0.86\right)$, vendar ne značilno različno od LsqMeOH $\left(\mathrm{A}_{450}, 0.84\right)$. Frakciji FR1 in FR3 sta imeli veliko manjšo absorbanco $\mathrm{Z}$ vrednostmi $\mathrm{A}_{450}, 0.21$ in $\mathrm{A}_{450}, 0.36$ pri $1 \mathrm{mg} \mathrm{ml}^{-1}$. Antioksidacijsko najaktivnejša frakcija (F3) je bila $v$ nadaljevanju analizirana $\mathrm{z}$ LC-MS/MS za pridobitev podrobnejše kemijske sestave. Uridin, derivat ganodermične kisline in flavonoidi so bili prvič najdeni v antioksidacijskih izvlečkih glive L. squarrosulus. Pridobljeni rezulati kažejo, da imajo frakcijski izvlečki glive L. squarrosulus antioksidacijske lastnosti in, da bi lahko bili uporabljeni kot lovilci prostih radikalov. Raziskava nakazuje, da je lahko gliva $L$. squarrosulus vir za antioksidacijske izvlečke za uporabo v prehrambeni industriji pri pripravi funkcionalne hrane.

Ključne besede: medicinske gobe; aktivne sestavine; Lentinus squarrosulus

\section{INTRODUCTION}

Oxidative stress is involved in the pathogenesis of lifestyle-related diseases, including atherosclerosis, hypertension, diabetes mellitus, ischemic diseases, and malignancies (Yoshikawa and Naito, 2002). Reiter reported the increased oxidative damage observed during aging is probably due to the deficiency of antioxidants (Reiter, 1995). Even though enzymatic antioxidants such as superoxide dismutase (SOD), glutathione peroxidase and catalase or nonenzymatic antioxidants such as vitamin E ( $\alpha$-tocopherol), vitamin

\footnotetext{
1 Department of Plant Protection, Faculty of Agriculture, Universiti Putra Malaysia, 43400 Serdang, Selangor, Malaysia. * Corresponding author: sumaiyah@upm.edu.my

2 Mushroom Research Centre, Institute of Biological Sciences, Faculty of Science, University of Malaya, 50603 Kuala Lumpur, Malaysia

3 Advanced Chemistry Solutions, 52200 Kuala Lumpur, Malaysia
} 
C (ascorbic acid), thiol antioxidants (glutathione), carotenoids and flavonoid compounds are useful for protection against free-radical damage they are still insufficient to prevent damage entirely (Rahman, 2007). Therefore, external sources of antioxidants from the diet are needed to compensate this unbalance situation. In most countries, strict governmental rules regarding the use of synthetic antioxidants has been imposed due to safety concerns associated with the toxicity studies (Wanasundara and Shahidi, 2005). Thus, exploring for natural antioxidant is necessary.

From previous studies, it is apparent that mushrooms have great potential as a source of novel compounds (Deiana et al., 2004; Lee and Yun, 2006; Chen et al., 2012). For instance, ergothionine was isolated from Pleurotus citrinopileatus Singer, P. ostreatus (Jacq. ex Fr.) P.Kumm and Pleurotus salmoneostramineus L.Vass., lovastatin from Pleurotus ostreatus and Agaricus bisporus (J.E.Lange) Imbach (Chen et al., 2012) and schizophyllan from Schizophyllum commune Fries (Bae et al., 2004). Some of these compounds have been developed as drugs as well as an ingredient in nutraceuticals. Mycelia of mushrooms serve as a convenient alternative to fruiting bodies due to the shorter incubation time, uniform and ease for higher production of biomass (Lee et al., 2004; Halpern, 2007). Moreover, the mycelial biomass can be produced in large quantities by using submerged fermentation technique.

Lentinus squarrosulus Mont. was amongst the commonly encountered Polyporales in Peninsular
Malaysia (Bolhassan et al., 2012). The nutrient content of $L$. squarrosulus mycelia has been analyzed. The authors (Omar et al., 2011) reported that the mycelia of L. squarrosulus is high on protein $(57.6 \%)$ and low on total fat $(0.5 \%)$ content, are rich in magnesium $(0.4 \%)$, potassium $(3.8 \%)$ and vitamin $\mathrm{B}_{3}(0.2 \%)$. Furthermore, they also investigated on anti-ulcerogenic activity of $L$. squarrosulus mycelia extract and proven that this extract was able to prevent and heal ulcer that is associated with the attenuation of proinflammatory cytokines IL- $1 \beta$ and the inhibition of NF- $k$ B in ulcerated rats.

The cupric reducing antioxidant capacity (CUPRAC) is based on utilizing the copper (II)-neocuproine reagent as the chromogenic oxidant. This assay is based on the redox reaction with antioxidants producing the cuprousneocuproine chelate $(\mathrm{Cu}(\mathrm{I})-\mathrm{Nc})$ stable complex showing maximum light absorption wavelength at 450 $\mathrm{nm}$ (Apak et al., 2004). As yet, no research has been established on the purification and identification of antioxidant compounds from $L$. squarrosulus mycelium grown by liquid fermentation. Hence, the objective of this study is to carry out CUPRAC-assay fractionation of antioxidant compounds from methanol extract of $L$. squarrosulus (LsqMeOH) mycelium using reversedphase high-performance liquid chromatography (RPHPLC). Confirmatory analysis using liquid chromatography (LC) combined with tandem (MS/MS) mass spectrometry approach is used to identify antioxidant compounds.

\section{MATERIALS AND METHODS}

\subsection{Sample preparation}

Mycelial culture of L. squarrosulus (KUM 50016) was obtained from Mycology Laboratory, Institute of Biological Sciences, University of Malaya and maintained on Glucose-Yeast-Malt-Peptone (GYMP) agar consisting of $\mathrm{MgSO}_{4} .7 \mathrm{H}_{2} \mathrm{O}\left(0.40 \mathrm{~g} \mathrm{l}^{-1}\right), \mathrm{KH}_{2} \mathrm{PO}_{4}$, $\left(0.40 \mathrm{~g} \mathrm{l}^{-1}\right) \mathrm{K}_{2} \mathrm{HPO}_{4},\left(0.40 \mathrm{~g} \mathrm{l}^{-1}\right)$ glucose $\left(4.00 \mathrm{~g} \mathrm{l}^{-1}\right)$, peptone, $\left(2.00 \mathrm{~g} \mathrm{l}^{-1}\right)$ malt-extract $\left(2.00 \mathrm{~g} \mathrm{l}^{-1}\right)$, agar $(7.20$ $\mathrm{g}^{-1}$ ). Seven days old $L$. squarrosulus mycelium grown on GYMP agar media at $25 \pm 2{ }^{\circ} \mathrm{C}$ was used as inoculum. Ten $7 \mathrm{~mm}$ diameter plugs of $L$. squarrosulus mycelium were inoculated into the $500 \mathrm{ml}$ Erlenmeyer flasks containing $100 \mathrm{ml}$ GYMP liquid medium and then incubated for 14 days at $25 \pm 2{ }^{\circ} \mathrm{C}$ under static conditions. After 14 days, mycelial biomass obtained were harvested and freeze-dried before proceeded with extraction process. Dried mycelial biomass of $L$. squarrosulus was extracted by soaking in methanol for two days at room temperature. The filtrate was concentrated under reduced pressure using a rotary evaporator (BüchiRotavapor R-114, Flawil, Switzerland) under $45^{\circ} \mathrm{C}$.

\subsection{Fractionation of Lentinus squarrosulus methanol extract by RP-HPLC}

Distilled water was pumped to remove air bubbles before use. All eluents except water were passed through a $0.2 \mu \mathrm{m}$ cellulose nitrate membrane (Whatman No. 1, Maidstone, England) filtration apparatus immediately before use. Distilled water was passed through a $0.45 \mu \mathrm{m}$ cellulose membrane filtration. The methanol extract of $L$. squarrosulus was applied onto an analytical reverse phase $(250 \mathrm{~mm} \times 4.6 \mathrm{~mm}, 5 \mu \mathrm{m}) \mathrm{C} 18$ ODS Hypersil column (Thermo Fisher Scientific, MA, USA) and analyzed by LC UV/VIS photodiode array detector SPD-M10 AVP (Shimadzu, Kyoto, Japan). The mobile phase consisted of $100 \%$ distilled water (solvent A) and $100 \%$ acetonitrile (Merck, Darmstadt, 
Germany) (solvent B) at a flow rate of $3.5 \mathrm{ml} \cdot \mathrm{min}^{-1}$. The gradient system started at $0.01 \mathrm{~min}(40 \% \mathrm{~B}), 3.00 \mathrm{~min}$ $(60 \% \mathrm{~B}), 4.00 \mathrm{~min}(80 \% \mathrm{~B}), 7.00 \mathrm{~min}(10 \% \mathrm{~B})$ and stopped at $8.00 \mathrm{~min}$. These various eluted fractions were collected and each fraction was assayed for CUPRAC.

\subsection{Cupric ion reducing antioxidant capacity (CUPRAC)}

The Cupric ion reducing antioxidant capacity (CUPRAC) was determined according to the method of Apak et al. (2004) based on the principle of utilizing copper (II)-neocuproine reagent as the chromogenic oxidizing agent. In this assay, $1 \mathrm{ml}$ of extracts were mixed with $1 \mathrm{ml}$ of Copper (II), $1 \mathrm{ml}$ of ammonium acetate $\left(\mathrm{NH}_{4} \mathrm{Ac}\right)$ buffer solution $(1 \mathrm{mM}, \mathrm{pH} 7.0)$ and 1 $\mathrm{ml}$ of neocuproine $(7.5 \mathrm{mM})$. The reaction mixture (total of $4 \mathrm{ml}$ ) then was mixed thoroughly and allowed to stand for 30 minutes before the absorbance was measured at $450 \mathrm{~nm}$ against a reagent blank. The assay was carried out in triplicate and the results expressed as means values \pm standard deviations.

\subsection{Profiling of chemical constituent by LC-MS/MS}

The constituents of the most active fraction were analyzed by HPLC tandem mass spectrometry (LCMS/MS). This procedure was done on an AB Sciex 3200QTrap ${ }^{\circledR}$ LC-MS/MS (Applied Biosystems, Toronto, Canada) triple quadropol mass spectrometer equipped with a Turbospray Ionization source. HPLC separation was carried out on a Phenomenex Aqua C18 column $(5 \mu \mathrm{m}, 50 \mathrm{~mm} \times 2.0 \mathrm{~mm}$ i.d.; Phenomenex, Torrance, California, US). A mobile phase gradient of water with $0.1 \%$ formic acid, $5 \mathrm{~mm}$ ammonium formate as eluent $\mathrm{A}$ and acetonitrile with $0.1 \%$ formic acid and $5 \mathrm{~mm}$ ammonium formate as eluent B. Samples were diluted with $1.0 \mathrm{ml}$ methanol and then filtered through $0.22 \mu \mathrm{m}$ nylon filter. Injection volume was $20 \mu \mathrm{l}$. A gradient program was used as follows: $10 \%$ A to $90 \%$ B from $0.01 \mathrm{~min}$ to $8.00 \mathrm{~min}$, held for $3.00 \mathrm{~min}$ and back to $10 \% \mathrm{~A}$ in $0.10 \mathrm{~min}$ and re-equilibrated for 4.00 min, the flow rate was changing between $250 \mathrm{ml} \mathrm{min}^{-1}$ to $400 \mathrm{ml} \mathrm{min}^{-1}$. The negative ion mode for MS/MS analysis was selected. Data analysis was carried out by using $\mathrm{AB}$ Sciex Analyst software and Advanced Chemistry Development, Inc (ACD/Labs, Toronto, Canada) software. Identification of constituents present in FR2 was performed by comparing the retention time and MS spectra of the peaks in the samples with those authentic reference samples or data reported in the literature.

\subsection{Statistical analysis}

For each antioxidant fraction (FR1, FR2 and FR3), assays were carried out in triplicates. The results were expressed as mean values and standard deviation (SD) or standard errors (SE). The results were analysed using one-way analysis of variance (ANOVA) followed by Tukey's HSD Test. Comparisons were carried out to detect significant difference $(p<0.05)$ between the mean values that had more than two groups. This treatment was carried out using SPSS v.16.0 software. The ANOVA results were classified using letters (different letters mean significant differences among results).

\section{RESULTS AND DISCUSSION}

\subsection{CUPRAC analysis of RP-HPLC isolates}

Separation by RP-HPLC resulted in three fractions collected at retention times of 2.8, 4.9 and $6.5 \mathrm{~min}$. The profile obtained at the detection wavelength of $254 \mathrm{~nm}$. The gradient system started at $0.01 \mathrm{~min}(40 \% \mathrm{~B}), 3.00$ $\min (60 \% \mathrm{~B}), 4.00 \min (80 \% \mathrm{~B}), 7.00 \min (10 \% \mathrm{~B})$ and stopped at $8.00 \mathrm{~min}$. Figure 1 shows the absorbance values of fraction 1 (FR1), fraction 2 (FR2), fraction 3 (FR3) and the crude extract (LsqMeOH). CUPRAC activity revealed FR1and FR3 having lower absorbance than FR2 and LsqMeOH. From the result obtained, FR2 exhibited the highest absorbance of $\left(\mathrm{A}_{450}, 0.86\right)$ but not significantly different $(p<0.05)$ from LsqMeOH with an absorbance of $\left(\mathrm{A}_{450}, 0.84\right)$. FR1 and FR3 showed much lower absorbance, with values $\left(\mathrm{A}_{450}, 0.21\right)$ and $\left(\mathrm{A}_{450}, 0.36\right)$ respectively. The antioxidant capacities showed that the LsqMeOH (crude) was higher than its active fraction (FR1and FR3) and comparable high to FR2. FR2 was subjected to LC-MS/MS analyses to profile the compounds present. Table 1 shows the masses of peaks and ion fragment productions detected by the LC-MS/MS analysis of this extracts. 


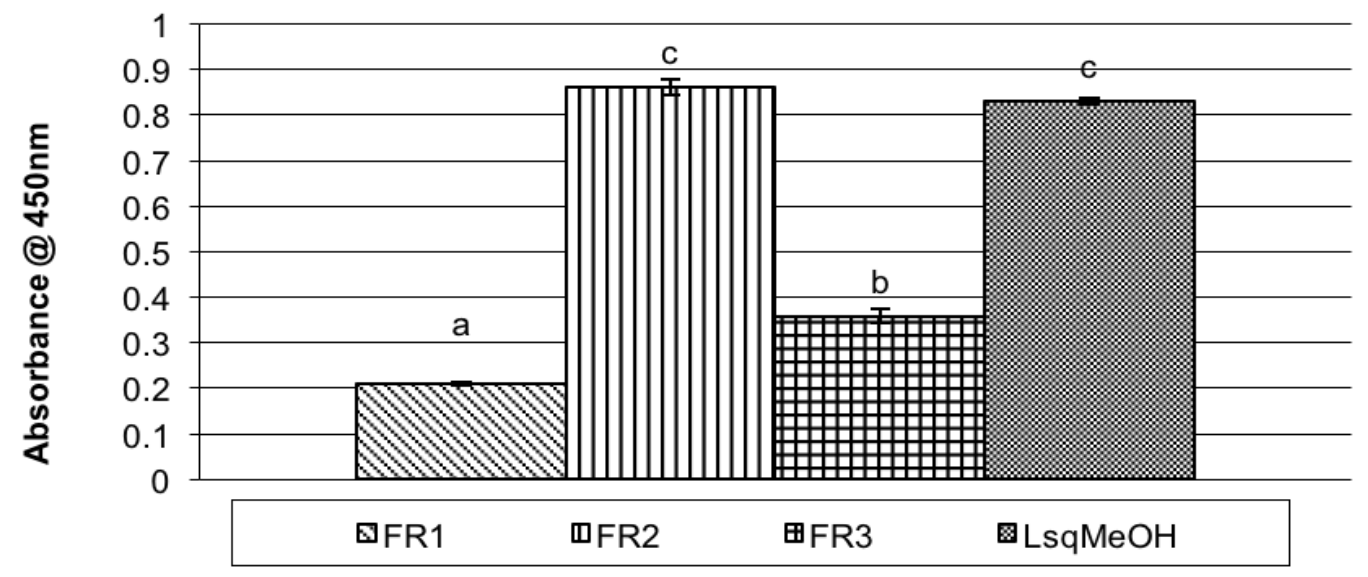

Figure 1: Reducing power of fraction RP-HPLC (FR1 to FR3) and LsqMeOH extracts on cupric ion. Concentration tested at $1 \mathrm{mg} \mathrm{ml}^{-1}$. Each value is expressed as mean \pm standard deviation $(n=3)$. Average values with different letters are significant at $p<0.05$

\subsection{Profiling of selected potent antioxidative extract constituent by LC-MS/MS}

From the LC-MS/MS data obtained (Table 1), Peak 1 was identified as uridine with mass fragments at $\mathrm{m} / \mathrm{z}$ (mass to charge ratio) 225, 200 and 140. From the fragmentation scheme (Figure 2), uridine produces $\mathrm{m} / \mathrm{z}$ ion at 200 with the loss of $-\mathrm{C}_{2} \mathrm{H}_{3} \mathrm{O}(-43)$ due to hemolytic cleavage at the side chain. Further fragment ions unique to uridine were also observed at $\mathrm{m} / \mathrm{z} 225$ formed by a loss of a $\mathrm{H}_{2} \mathrm{O}$ molecule and at $\mathrm{m} / \mathrm{z} 140$ due to further hydrogen rearrangements and hemolytic cleavage. Uridine is known to be one of the four basic components of ribonucleic acid (RNA) and it plays a role in the glycolysis pathway of galactose (Berg et al., 2002). Nucleosides including adenosine, cytidine, uridine, guanosine, inosine and thymidine had been isolated from Cordyceps (Li et al., 2006). A study by $\mathrm{Yu}$ et al. (2006) showed that uridine has antioxidant activities. They reported that uridine from Cordyceps sinensis (Berk.) Sacc. and Cordyceps militaris (L.) Fr. extracts have Trolox Equivalent Antioxidant Capacity value of $2.0 \pm 0.9 \mu \mathrm{g} / \mathrm{ml}$.

Table 1: Masses of peaks and ion fragments productions detected by LC-MS/MS of FR2

\begin{tabular}{lcccll}
\hline $\begin{array}{c}\text { Peak } \\
\text { no. }\end{array}$ & $\begin{array}{c}\text { Rt } \\
(\mathrm{min})\end{array}$ & MW & $\begin{array}{c}\text { MS, M/Z }[\text { M- } \\
\text { H] }\end{array}$ & \multicolumn{1}{c}{ Fragment } & \multicolumn{1}{c}{ Detected compound } \\
\hline 1 & 0.80 & 244 & 243 & $225,200,140$ & Uridine \\
2 & 1.28 & 228 & 227 & $183,181,155,140,127,82$ & Phenolic acid \\
& & & & & \\
3 & 1.93 & 299 & 298 & $254,236,223,193,179,167$ & Phenolic acid \\
& & & & & \\
4 & 2.25 & 242 & 241 & $197,168,141,130,82$ & Phenolic acid \\
5 & 3.21 & 276 & 275 & $231,147,127,109$ & Unknown \\
6 & 3.69 & 498 & 497 & 451,433 & Ganoderic acid derivative \\
7 & 4.17 & 725 & 724 & 724,678 & Unknown \\
8 & 8.50 & 312 & 311 & $293,225,183$ & Flavonoids \\
9 & 8.82 & 326 & 325 & $225,197,183$ & Flavonoids \\
10 & 9.14 & 340 & 339 & $293,197,183$ & Flavonoids \\
11 & 9.62 & 874 & 873 & 647,607 & Unknown \\
\hline
\end{tabular}


Peaks 2, 3, and 4 had masses corresponding to phenolic acid group of compounds. This is due to the fact that all these peaks have a common loss of carbon dioxide molecule $\left(-\mathrm{CO}_{2},-44\right)$, which is characteristic of carboxylic-based compounds. Phenolic acid received considerable attention in the literature, specifically because of their biological and physiological importance. In a study of phenolic acids determination by HPLC-DAD-ESI/MS in sixteen different Portuguese wild mushrooms species, Barros et al. (2009) reported that various phenolic acids such as protocatechuic, $p$ hydroxybenzoic and p-coumaric acids, and two vanillic acid isomers were detected. $p$-Hydroxybenzoic acid exhibited in the majority of the samples tested and also being the most abundant compound in Agaricus silvicola (Vittad.) Peck $\left(238.7 \mathrm{mg} \mathrm{kg}^{-1}\right)$. In the same study, Ramaria botrytis (Pers.) Ricken showed the highest phenolic acids concentrations (356.7 mg. $\mathrm{kg}^{-1}$ ) due to the significant contribution of protocatechuic $\operatorname{acid}\left(342.7 \mathrm{mg} \mathrm{kg}^{-1}\right)$.

A type of ganoderic acid derivative was also determined from the FR2 extract. This finding contradicts Xu et al. (2010) who claimed that Ganoderma spps. are the only known producer for ganoderic acid. Peak number 6 (Table 1) had a mass corresponding to ganoderic acid [M-H] ion at $\mathrm{m} / \mathrm{z}, 497$ produced a fragment ion with $\mathrm{m} / \mathrm{z}$ 451 and 433 . When applied to a collision energy spread of $35 \mathrm{eV}(+/-15)$, the ganoderic acid compound produces ion $\mathrm{m} / \mathrm{z} 451$ formed by sequential loss of a water molecule $\left(-\mathrm{H}_{2} \mathrm{O},-18\right)$, followed by carbon dioxide ($\mathrm{CO}_{2}$, -44) followed by re-arrangement process at the side chain, as shown in the schematic diagram below (Figure 3). A further loss of an $\mathrm{H}_{2} \mathrm{O}$ molecule formed the next fragment ion at $\mathrm{m} / \mathrm{z}$ 433. Ganoderic acid was proven to exhibit significant pharmacological activities by means of anti-histamine, anti-hypercholesterolemic, antibacterial and capacity to scavenge free radicals (Kohda et al., 1985; Komoda et al., 1989; Zhu et al., 1999; Wang and Liu, 2008). Other research has implicated that ganoderic acid DM isolated from Ganoderma lucidum (Curtis) P. Karst. inhibits cell proliferation and colony formation in MCF7, human breast cancer cells (Wu et al., 2012). Triterpene, a type of ganoderic acid, from G. lucidum was antiviral, specifically towards HIV (El-Mekkawy et al., 1998). Terpene and polysaccharide fractions were obtained from $G$. lucidum in a study on antioxidative activity by bioassay guided isolation (Zhu et al., 1999). Results showed that terpene fraction possesses the highest activity at $40 \mu \mathrm{g} \mathrm{ml}^{-1}$ against iron (II)-ascorbic acid induced lipid peroxidation, chemical isolation of the terpene fraction resulted in the detection of ganoderic acid A, B, C and D, lucidenic acid B and ganodermanontriol. 


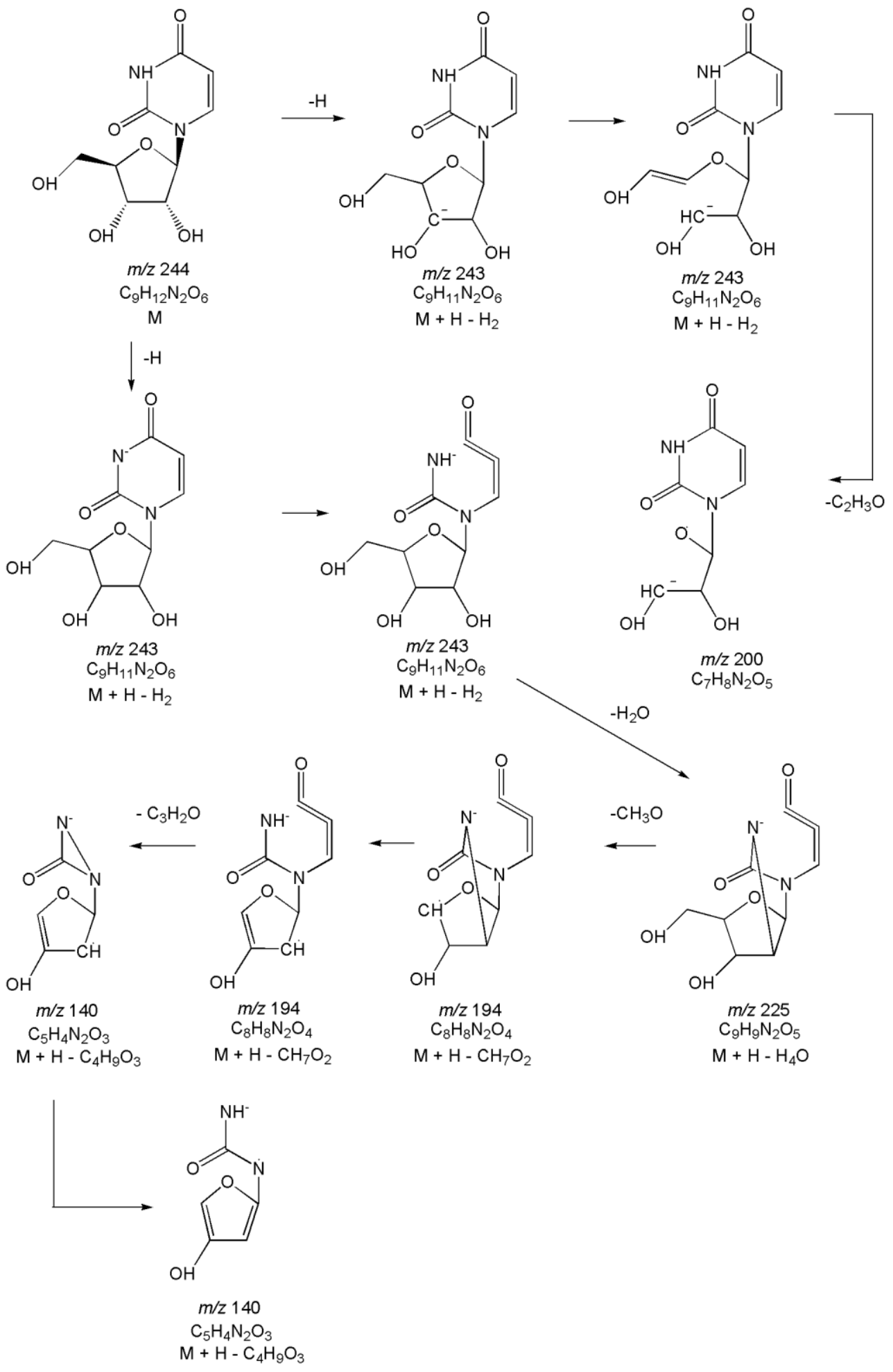

Figure 2: Uridine fragmentation pathway scheme

Peaks 8, 9 and 10 for FR2 (Table 1) have masses corresponding to flavonoid compounds. For peak 8 with $\mathrm{m} / \mathrm{z}$ parent mass of $311(\mathrm{M})$, the fragment ion observed was 293 , which correspond to a loss of $\mathrm{H}_{2} \mathrm{O}$ and other fragment ions were $\mathrm{m} / \mathrm{z} 225$ and 183 . The fragment ion at $m / z 225$ was most likely the loss of M-H- $\mathrm{C}_{2} \mathrm{H}_{2} \mathrm{O}-\mathrm{CO}_{2}$, and further loss of $\mathrm{C}_{2} \mathrm{H}_{2} \mathrm{O}$ that corresponds to the ion $m / z$ 183. This fragmentation pathway usually corresponds to compounds from the class flavonoids, probably for apigenin, as reported by Wu et al. (2004) 
which showed such a fragmentation pathway. Peaks 9 and 10, which correspond to $\mathrm{m} / \mathrm{z} \quad 325$ and 339 respectively, also shared similar fingerprint fragment ions (Table 1). Both the masses differ by a mass of 14 sequentially. This showed most likely to be carbon and hydrogen rearrangements of $\mathrm{CH}_{2}$ to form both compounds that are derivatives from compound Peak 8 (Table 1). Flavonoids can be subdivided into six main subclasses namely flavones, flavonols, flavan-3-ols, isoflavones, flavanones and anthocyanidins. Other flavonoid groups, which quantitatively are in comparison, minor components of the diet, are dihydroflavonols, flavan-3, 4-diols, coumarins, chalcones, dihydrochalcones and aurones (Crozier et al., 2006). Methanol extracts from cultivated fruiting bodies of endophytic fungus Xylaria sp. YX-28, are rich in phenolics and flavonoids with $54.51 \mathrm{mg} \mathrm{GAE} \mathrm{g}^{-1}$ dry mass and $86.76 \mathrm{mg} \mathrm{RE} \mathrm{g}^{-1}$ dry mass respectively (Liu et al., 2007). The total phenols and among them flavonoids were the major components found in the mushroom extract of Lactarius deliciosus (L.) Gray, Sarcodon imbricatus (L.) P. Karst., and Tricholoma portentosum (Fr.) Quèl (Barros et al., 2007). Flavonoids have been considered as important antioxidants for health and were reported to play an important role in the prevention of lipid peroxidation and cardiovascular disease (Peng and Kuo, 2003; Ding et al., 2006). Several unknown compounds were also detected in this study. Three unknown compounds for FR2 that were represented by peak numbers 5, 7 and 11 (Table 1). A match for the mass spectrum of unknown compounds could not be found from both the database and literature.<smiles>CC(CC(=O)C[C@@H](C)C1C=C[C@]2(C)C3=C(C(=O)C[C@]12C)[C@@]1(C)CCC(=O)C(C)(C)[C@@]1(C)C[C@H]3O)C(=O)O</smiles>

MW 498<smiles>CC(CC(=O)C[C@H](C)[C@]1(C)C=C[C@]2(C)C3=C(C(=O)C[C@]21C)[C@@]1(C)CCC(=O)C(C)(C)[C@@]1(C)C[C@H]3O)C(=O)O</smiles>

$m / z 497$

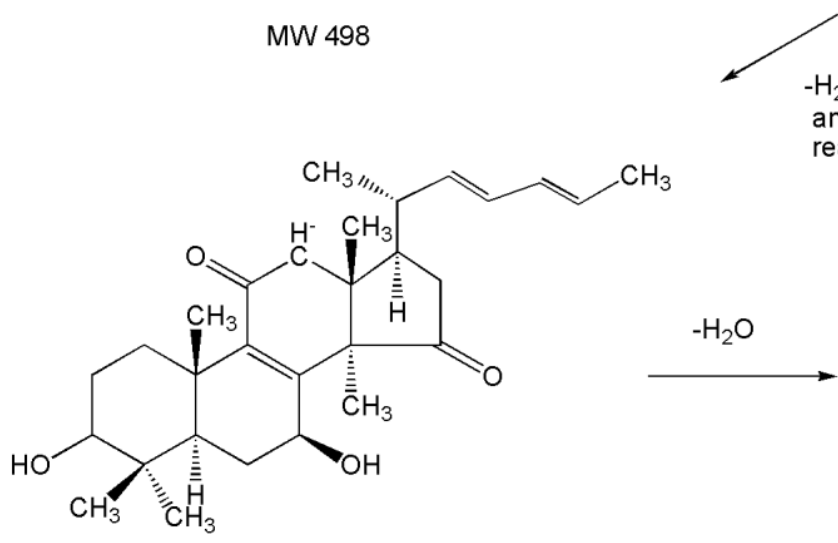

$m / z 451$<smiles>O=C(O)O</smiles>
and side chain rearrangement<smiles>C/C=C/C=C/[C@@H](C)[C@H]1CC(=O)[C@]2(C)C3=C(C(=O)C[C@]12C)[C@@]1(C)CC=CC(C)(C)[C@]1(C)C[C@H]3O</smiles>

$m / z 433$

Figure 3: Ganoderic acid derivative fragmentation pathway scheme

\section{CONCLUSIONS}

Compounds contributing to antioxidant capacities from Lentinus squarrosulus Mont. are varied and between them in the complex system such as food sources and foodstuff there exist interactions and synergistic effect, therefore rather than a single compound it is preferred to use them as a whole. Chang and Buswell (2003) reported that the combination of several individual components contributed to the overall medicinal effect of the mushroom-based nutraceutical products. In this study, the potent antioxidant fraction from $L$. squarrosulus has been standardized by HPLC to contain phenolic-based compound, ganoderic acid derivative, uridine and flavonoids. The use of this extract as nutraceutical ingredient must conform to this standardized component to ensure quality and potency. Furthermore, L. squarrosulus mycelial antioxidant 
extract is non toxic based on our previous study in experimental rats. It contains absorbable antioxidants that enter the circulating plasma and cause a significant acute increase in plasma antioxidant capacity (Omar et al., 2015). Therefore, this study validates the potential use of L. squarrosulus Mont. as an alternative source of natural antioxidant for nutraceuticals and pharmaceuticals industries.

\section{ACKNOWLEDGMENTS}

The authors would like to thank University of Malaya for grants P0138/2006C, PS083/2007B, PS234/2008C and High Impact Research MOE Grant
UM.C/625/1/HIR/MoE/SC/02 from the Ministry of Education Malaysia.

\section{REFERENCES}

Apak, R., Güclü, K., Özyürek, M. \& Karademir, S. E. (2004). Novel total antioxidant capacity index for dietary polyphenols and vitamin $\mathrm{C}$ and $\mathrm{E}$, using their cupric ion reducing capability in the presence of neocuproine: CUPRAC method. Journal of Agriculture and Food Chemistry, 52, 7970-7981. doi:10.1021/jf048741x

Bae, A. H., Lee, S.W., Ikeda, M., Sano, M., Shinkai, S., Sakurai, K. (2004). Rod-like architecture and helicity of the $\operatorname{poly}(\mathrm{C}) / \mathrm{schizophyllan}$ complex observed by AFM and SEM. Carbohydrate Research, 339, 251-258. doi:10.1016/j.carres.2003.09.032

Barros, L., Calhelha, R. C., Vaz, J. A., Ferreira, I. C. F. R., Baptista, P. \& Estevinho, L. M. (2007). Antimicrobial activity and bioactive compounds of Portuguese wild edible mushrooms methanolic extracts. European Food Research and Technology, 225, 151-156. doi:10.1007/s00217-006-0394-x

Barros, L., Duenas, M., Ferreira, I. C. F. R., Baptista, P., Santos-Buelga, C. (2009). Phenolic acids determination by HPLC-DAD-ESI/MS in sixteen different Portuguese wild mushrooms species. Food and Chemical Toxicology, 47, 1076-1079. doi:10.1016/j.fct.2009.01.039

Berg, J. M., Tymoczko, J. L. \& Stryer L. (2002). Biochemistry (5th ed.). New York, NY: W H Freeman.

Bolhassan, M. H., Abdullah, N., Sabaratnam, V., Tsutomu, H., Abdullah, S., Rashid, N. M. N. \& Musa, M. Y. (2012). Diversity and distribution of Polyporales in Peninsular Malaysia. Sains Malaysiana, 41, 155-161.

Chang, S. T. \& Buswell, J. A. (2003). Medicinal mushrooms- A prominent source of nutriceuticals for the 21st century. Current Topics in Nutraceutical Research, 1, 257-280.
Chen, S. Y., Ho, K. J., Hsieh, Y. J., Wang, L. T., Mau, J. L. (2012). Contents of lovastatin, $\gamma$-aminobutyric acid and ergothioneine in mushroom fruiting bodies and mycelia. LWT- Food Science Technology, 47, 274-278. doi:10.1016/j.lwt.2012.01.019

Crozier, A., Jaganath I. B. \& Clifford M. N. (2006). Phenols, polyphenols and Tannins: An overview. In A. Crozier, M. N. Clifford and H. Ashihara (Eds.), Plant secondary metabolites: Occurrence, structure and role in the human diet (pp. 2-3). Oxford, UK: Blackwell Publishing Ltd. doi:10.1002/9780470988558.ch1

Deiana, M., Rosa, A., Casu, V., Piga, R., Dessí, M. A., \& Aruoma, O. I. (2004). L-ergothioneine modulates oxidative damage in the kidney and liver of rats in vivo: Studies upon the profile of polyunsaturated fatty acids. Clinical Nutrition, 23, 183-193. doi:10.1016/S0261-5614(03)00108-0

Ding, E. L, Hutfless, S. M., Ding, X., \& Girotra, S. (2006). Chocolate and prevention of cardiovascular disease: A systematic review. Nutrition \& Metabolism, 3. Retrieved from doi:10.1186/17437075-3-2 doi:10.1186/1743-7075-3-2

El-Mekkawy, S., Meselhy, M. R., Nakamura, N., Tezuka, Y., Hattori, M., Kakiuchi, N., Shimotohno, K., Kawahata, T., \& Otake, T. (1998). Anti-HIV-1 and anti-HIV-1- protease substances from Ganoderma lucidum. Phytochemistry, 49, 16511657. doi:10.1016/S0031-9422(98)00254-4

Halpern, G. M. (2007). Mushroom cultivation. In G. M. Halpern (Ed.), Healing mushrooms: Effective treatments for today's illnesses (pp. 121-123). Garden City Park, New York, NY: Squares One Publishers.

Kohda, H., Tokumoto, W., Sakamoto, K., Fujii, M., Hirai, Y., Yamasaki, K., Komoda, Y., Nakamura, H., Ishihara, S., \& Uchida, M. (1985). The biologically active constituents of Ganoderma lucidum (Fr.) Karst. Histamine release-inhibitory 
triterpenes. Chemical and Pharmaceutical Bulletin, 33, 1367-1374. doi:10.1248/cpb.33.1367

Komoda, Y., Shimizu, M., Sonoda, Y., \& Sato, Y. (1989). Ganoderic acid and its derivatives as cholesterol synthesis inhibitors. Chemical and Pharmaceutical Bulletin, 37, 531-533. doi:10.1248/cpb.37.531

Lee, B. C., Bae, J. T., Pyo, H. B., Choe, T. B., Kim, S. W., Hwang, H. J., \& Yun, J. W. (2004). Submerged culture conditions for the production of mycelia biomass and exopolysaccharides by the edible Basidiomycete Grifola frondosa. Enzyme and Microbiological Technology, 35, 369-376. doi:10.1016/j.enzmictec.2003.12.015

Lee I. K., \& Yun B. S. (2006). Hispidin analogs from the mushroom Inonotus xeranticus and their free radical scavenging activity. Bioorganic and Medical Chemistry Letters, 16, 2376-2379. doi:10.1016/j.bmcl.2006.01.121

Li, S. P., Yang, F. Q., \& Tsim, K. W. (2006). Quality control of Cordyceps sinensis, a valued traditional Chinese medicine. Journal of Pharmaceutical and Biomedical analysis, 41, 1571-1584. doi:10.1016/j.jpba.2006.01.046

Liu, X., Dong, M., Chen, X., Jiang, M., Lv, X., \& Yan, G. (2007). Antioxidant activity and phenolics of an endophytic Xylaria sp. from Ginkgo biloba. Food Chemistry, 105, 548-554. doi:10.1016/j.foodchem.2007.04.008

Omar, N. A. M., Abdullah, N., Kuppusamy, U. R., Abdulla, M. A., \& Sabaratnam, V. (2011). Nutritional composition, antioxidant capacity and antiulcer potential of Lentinus squarrosulus (Mont.) mycelia extract. Evidenced-Based Complementary and Alternative Medicine. doi:10.1155/2011/539356

Omar, N. A. M., Abdullah, S., Abdullah, N., Kuppusamy, U. R., Abdulla, M. A., \& Sabaratnam, V. (2015). Lentinus squarrosulus (Mont.) mycelium enhanced antioxidant status in rat model. Drug Design, Development and Therapy, 9, 59575964.

Peng, I. W., \& Kuo, S. M. (2003). Flavanoid structure affects the inhibition of lipid peroxidation in Caco2 intestinal cells at physiological concentration. The Journal of Nutrition, 133, 2184-2187. doi:10.1093/jn/133.7.2184
Rahman, K. (2007). Studies on free radicals, antioxidants, and co-factors. Clinical Interventions in Aging, 2, 219-236.

Reiter, R. J. (1995). Oxidative process and antioxidative defense mechanism in aging brain. FASEB Journal, 9, 526-533. doi:10.1096/fasebj.9.7.7737461

Wanasundara, P. K. J. P. D., \& Shahidi, F. (2005). Antioxidants: Science, technology, and applications. In F. Shahidi (Ed.), Bailey's industrial oil and fat products (6th ed.), (pp. 431-489). New York, NY: John Wiley \& Sons, Inc. doi:10.1002/047167849X.bio002

Wang, X. L., \& Liu, Z. T. (2008). In vitro bacteriostasis of the intracellular ganoderic acids from the mycelium of Ganoderma lucidum. Food Science Technology, 10, 184-186.

Wu, G. S., Lu, J. J., Guo, J. J., Li, Y. B., Tan, W., Dang, Y. Y., Zhong, Z. F., Xu, Z. T., Chen, X. P., \& Wang, Y. T. (2012) Ganodermic acid DM, a natural triterpenoid, induces DNA damage, G1 cell cycle arrest and apoptosis in human breast cancer cells. Fitoterapia, $\quad 83, \quad 408-414$. doi:10.1016/j.fitote.2011.12.004

Wu, W., Yan, C., Li, L., Liu, Z., \& Liu, S. (2004). Studies on the flavones using liquid chromatography-electrospray ionization tandem mass spectrometry. Journal of Chromatography A, 1047, 213-220. doi:10.1016/S0021-9673(04)011355

Xu, J. W., Zhao, W., \& Zhong, J. J. (2010). Biotechnological production and application of ganoderic acids. Applied Microbiology and Biotechnology, 87, 457-466. doi:10.1007/s00253010-2576-5

Yoshikawa, T., \& Naito, Y. (2002). What is oxidative stress? Japan Medical Association Journal, 45, 271-276.

Yu, H. M., Wang, B. S., Huang, S. C., \& Duh, P. D. (2006). Comparison of protective effects between Cordyceps militaris and natural Cordyceps sinensis against oxidative damage. Journal of Agriculture and Food Chemistry, 54, 3132-3138. doi:10.1021/jf053111w

Zhu, M., Chang, Q., Wong, L. K., Chong, F. S., \& Li, R. C. (1999) Triterpene antioxidants from Ganoderma lucidum. Phytotherapy Research, 13, 529-531. doi:10.1002/(SICI) 10991573(199909)13:6<529::AID-PTR481>3.0.CO;2-X 